\title{
IMPLEMENTATION OF THE ESTABLISHMENT A PILOT PROJECT FOR A CHILD-FRIENDLY SCHOOL IN KABUPATEN KAUR BENGKULU
}

\author{
Dessy Sunarsi $^{1 *}$, Merry Safarwaty ${ }^{2}$, Daesy Ekayanti ${ }^{2}$, Ekaterina Setyawati $^{3}$, Ira Mulyati ${ }^{3}$ \\ ${ }^{1}$ Faculty of Law, Sahid University, Jakarta, ${ }^{2}$ Faculty of Communication Science, Sahid University, Jakarta, \\ ${ }^{3}$ Faculty of Engineering, Sahid University, Jakarta \\ *dessynew@ymail.com
}

\begin{abstract}
Child Friendly Schools are schools / madrasas that are safe, clean, healthy, green, inclusive and comfortable for the physical, cognitive and psychosocial development of girls and boys including children who require special education and / or special service education; which openly involves children to participate in all activities, social life, and encourage children's growth and prosperity. The Child Friendly School Program launched by the government aims to improve the mainstreaming of children's rights in Indonesia. In the Province of Begkulu there is no Child Friendly School. Kaur Regency is currently a pilot district for the development of primary and secondary education in the province of Bengkulu. The determination of the pilot project for Child Friendly Schools is conducted by coordinating with the Education and Culture Office of Kaur Regency. For elementary school level, SDN 41 Kaur was chosen, given the school's reputation, strategic location and their readiness to implement this program. For the junior high school level, there were selected 36 PKLK junior high schools (Special Education Special Services). This school is boarding and for 24 hours students are in a school environment, students from disadvantaged groups. This socialization activity uses lecture methods, discussion and film visualization. The lecture method aims to provide a foundation of understanding of child-friendly school programs and discussion methods aimed at perfecting understanding. Film visualization method is given to strengthen the understanding of the community / students in the form of motivational impressions in order to want to implement this program. The output of the activity is the formation of child-friendly pilot elementary and junior high schools and public awareness of the needs of Child Friendly Schools in Kaur District.
\end{abstract}

Keywords: Child Friendly Schools, growth and development, child protection, public awareness

\section{INTRODUCTION}

One of the items demanded by Indonesian children to the government at the 2016 Indonesian Children's Congress in Mataram is to make schools and our curriculum child-friendly to remote areas. Child Friendly Schools are schools that consciously strive to guarantee and fulfill children's rights in every aspect of life in a planned and responsible manner. The main principle is non-discrimination of interests, the right to life and respect for children. As in Article 4 of Law No.23 of 2002 concerning child protection, states that children have the right to live to grow, develop, and participate naturally according to human dignity and dignity, and to get protection from violence and discrimination. is participating which is described as the right to express and be heard.

This was translated by the Ministry of Women's Empowerment and Child Protection in the State Minister's Regulation No. 8 of 2014 regarding the Policy of Child Friendly Schools to define Child Friendly Schools as a safe, clean, healthy, caring and cultured environment for formal, non-formal and informal education units. guarantee, fulfill, respect children and protect children from violence, discrimination and other mistreatments and support children's participation, especially in planning, policy, learning, supervision, and complaints mechanisms related to the fulfillment of rights and protection of children and education.

In an effort to realize a Child Friendly School needs to be supported by various parties including family and community which is actually the closest education center for children. A supportive 
environment, protecting giving children a sense of security and comfort will greatly help the process of finding identity. The habit of children having a tendency to imitate, try and seek recognition of their existence in the environment in which they live.KabupatenKaur is a district in the province of Bengkulu located about $250 \mathrm{~km}$ from the capital city of Bengkulu,Kaur has an area of 2,369.05 km2 and is inhabited by at least 298,176 people. They rely on living from agriculture, gardening and fisheries. Kaur residents are spread in 15 sub-districts, 191 villages and 4 villages.

Kaur Regency was formed based on Law Number 3 Year 2003 in 2003. The previous Kaur was a part of South Bengkulu Regency.

Table 1: Populationof Kaur Regency Accordinhto District Year 2016

\begin{tabular}{|c|l|l|l|l|}
\hline \multirow{2}{*}{ Number } & \multicolumn{1}{|c|}{ Districts } & Male & Famale & Amount \\
& & & & \\
\hline 1 & Nasal & 9,023 & 7,759 & 16,782 \\
\hline 2 & Maje & 7,676 & 6,612 & 14,288 \\
\hline 3 & Kaur Selatan & 8,041 & 7,819 & 15,860 \\
\hline 4 & Tetap & 3,055 & 2,963 & 6,018 \\
\hline 5 & Kaur Tengah & 2,224 & 2,241 & 4,465 \\
\hline 6 & Luas & 2,528 & 2,404 & 4,932 \\
\hline 7 & MuaraSahung & 2,968 & 2,590 & 5,558 \\
\hline 8 & Kinal & 2,231 & 2,135 & 4,366 \\
\hline 10 & SemidangGumay & 2,812 & 2,710 & 5,522 \\
\hline 11 & TanjungKemuning & 5,630 & 5,460 & 11,090 \\
\hline 12 & Kelam Tengah & 3,213 & 3,108 & 6,321 \\
\hline 13 & Kaur Utara & 3,334 & 3,241 & 6,575 \\
\hline 14 & Padang GuciHilir & 1,870 & 1,815 & 3,685 \\
\hline 15 & LungkangKule & 1,722 & 1,668 & 3,390 \\
\hline 16 & Padang GuciHulu & 3,547 & 3,406 & 6,953 \\
\hline 17 & Kaur & 59,875 & 55,930 & 115,805 \\
\hline
\end{tabular}

Based on the data in Table 1, the male population is equal in number to the female population. Thus, women are potential human resources as a driving force for the family economy. However, the problem is that a strong patriarchal culture has placed women in a difficult position to gain access to capacity building. This fact causes women not yet able to empower themselves as economic drivers for their families and communities.Human resources that are not less important and become a milestone in development are children. Children are national assets that have rights that must be fulfilled in their growth and development. One of the children's rights is the right to access education. Every child has the right to get a decent education. Decent education does not only include the participation of children in educational institutions, but the needs of supporters to attend education; such as books, stationery, uniforms, conducive learning environments. Child Friendly Schools are open schools that involve children to participate in all activities, social life, and encourage children's growth and prosperity. Child Friendly Schools are schools / madrasas that are safe, clean, healthy, green, inclusive and comfortable for the physical, cognitive and psychosocial development of girls and boys including children who need special education and / or special service education and as pilot districts in the field education development in Bengkulu province, so that Kaur district should have Child Friendly Schools.

The description above shows that the development of Kaur Regency must be directed towards comprehensive rural development based on sustainable agriculture in accordance with the culture and local wisdom of Kaur which can empower women's economy and the mainstreaming of children's rights. For this reason, this activity is expected to initiate the realization of development in Kaur Regency through women's economic empowerment programs and mainstreaming children's rights. The objectives of the activities are: 1) Increase awareness of the community about children's rights; 2) Establish a Pilot Project for a child-friendly school in Kaur Regency; and 3) Increasing the participation of the Kaur Regency community to quality children's education.

Objectives Counseling and outreach in the context of establishing child-friendly schools in South Kaur District include: 
1. Pilot Project for Child Friendly Schools at 1 (one) primary school level and 1 (one) fruit school at South Kaur Subdistrict: Leaders and Teachers

2. Mainstreaming children's rightsCounseling and socialization of Child Friendly Schools to:

- Representatives of parents of students of SDN 41 and SMPN 36 in the District of South Kaur.

- Representative of elementary and junior high school teachers in South Kaur District

The output produced and can be managed by the Kaur Regency Residents Association (PWK)

Jabodetabek who have contributed to the results. The establishment of Child Friendly Elementary and Junior High Schools.

1. The formation of public awareness of the needs of Child Friendly Schools in Kaur District.

2. The establishment of Child-friendly pilot Elementery and Junior High School.

3. The increasing role of parents and the quality of communication with children.

\section{THEORETICAL OF FRAMEWORK}

Schools are institutions that have the mandate to carry out the process of education and learning systematically and continuously. Educators and education staff in schools are expected to carry out education and learning that is able to facilitate students to behave in an educated manner. Educated behavior is displayed in the form of academic achievement, demonstrating ethical behavior and nobility, high learning motivation.Principles of Organizing Child Friendly Schools:

There are several principles that can be applied to build child-friendly schools, including:

1. Schools are required to be able to present themselves as a media, not just a place that is fun for children to learn.

2. The world of children is "playing". In playing it is actually the child doing the learning and work process. Schools are playgrounds that introduce healthy competition in a teaching and learning process.

3. Schools need to create space for children to talk about their schools. The aim is to make a dialectic between the value given by education to children.

4. Educators do not need to feel threatened by the assessment of students because basically values do not add to the reality or substance of objects, but only values. Values are not objects or elements of objects, but rather the nature, quality, and generality of certain objects that are said to be "good". (Risieri Frondizi, 2001: 9)

5. Schools are not a world that is separated from the daily reality of children in the family because the achievement of a child's goals cannot be separated from everyday reality. Limitations of class hours and binding curriculum become obstacles to interpreting more deeply the interaction between educators and children. To get around this, the school can hold special hours outside school hours which contains sharing between children and sharing between teachers and children about the reality of their lives in their families, for example: discussion of how relationships with parents, what parents react when they get bad grades at school, or what parents expect of them. The results of the meeting can be a material of reflection in a subject matter delivered in class. This method is a strategy for educators to know the condition of the child because in some communities, children are considered family investment, as a guarantee of a place to depend on old age (Yulfita, 2000: 22).

\section{METHOD}

\section{Program preparation}

Activities include preparation of tools, materials and power point materials on Child Friendly School Guidelines as well as consultations with the ministry of PPPA CQ ASDEP Development and Development of Mother Daughter Dra. Elvy and coordinating activities with the regional secretary of the Kua rbapak district, ... and the head of the Kaur district education office.

\section{Implementation}

These counseling and socialization activities use lecture methods, discussion and film visualization. The lecture method is used to provide a foundation of understanding of child-friendly school programs. Furthermore, the discussion method was carried out to improve their understanding through question and answer. While the film visualization method is given to strengthen the 
understanding of the community / students about what they have understood through lectures and discussions. In this case, film visualization is programmed to be given in the form of motivational shows to move the community to want to implement this program.

\section{RESULT AND DISCUSSION}

The socialization activities for child-friendly schools in Kaur district were carried out together with the activities of the Sahid University Gender Study Center in empowering women's economy and following a schedule coordinated by the Sahid University Gender Study Center in Jakarta with the Kaur Regency Government. Activities in Kaur Regency were held on December 13-16, 2016. Activity schedules as listed in the Table. 2

Table 2. Schedule of Activities for Opening Activities of women's economicempowerment and mainstreaming children's rights in Kaur Regency

\begin{tabular}{|c|c|c|c|c|c|}
\hline No & Day/date & Time & $\begin{array}{l}\text { Description } \\
\text { of activities }\end{array}$ & Place & information \\
\hline 1. & $\begin{array}{l}\text { Tuesday, } \\
\text { December } \\
132016\end{array}$ & $\begin{array}{l}07.00-08.30 \\
\text { Wib }\end{array}$ & $\begin{array}{l}\text { Child-Friendly School } \\
\text { Socialization To Leaders of } \\
\text { Elementary / Middle / High } \\
\text { Schools in Kaur District and } \\
\text { the distribution of SRA } \\
\text { brochures }\end{array}$ & $\begin{array}{l}\text { Pentagon } \\
\text { SMA room }\end{array}$ & $\begin{array}{l}\text { Speaker: } \\
\text { a. SusmawarniTaher, } \\
\text { SPsi, M.Psi } \\
\text { b. Eka Terina } \\
\text { Setiowaty S.T.,MSi } \\
\text { c. Merry Safarwati, } \\
\text { S.Sos, M.Si }\end{array}$ \\
\hline 2. & $\begin{array}{l}\text { Tuesday, } \\
\text { December } \\
132016\end{array}$ & $\begin{array}{ll}08.30 & -10.00 \\
\text { Wib } & \end{array}$ & $\begin{array}{l}\text { Opening Ceremony } \\
\text { a. Opening by MC } \\
\text { b.Singing Indonesia Raya } \\
\text { c. Welcome speech from } \\
\text { Chairman PWKof } \\
\text { Jabodetabek. } \\
\text { d. WelcomeSpeech from the } \\
\text { Chancellor University of } \\
\text { Sahid Jakarta } \\
\text { e.Speech from the District } \\
\text { Secretary of Kaur, as well } \\
\text { as officially opening } \\
\text { activities of Food } \\
\text { Processed Bimtek and } \\
\text { woven crafts as well as } \\
\text { child friendly school } \\
\text { counseling } \\
\text { f. Giving award plaque } \\
\text { s by Sahid University to the } \\
\text { Kaur Regency } \\
\text { Government } \\
\text { c. Prayer together } \\
\text { d. Group photo }\end{array}$ & $\begin{array}{l}\text { Auditorium } \\
\text { of BAPEDA } \\
\text { Building }\end{array}$ & $\begin{array}{l}\text { Public Relations is led } \\
\text { by MC } \\
\text { Executive Secretary of } \\
\text { PWK Mrs. Ely Dasna } \\
\text { Taher } \\
\text { Represented by the } \\
\text { Chairman of PSG } \\
\text { Usahid Jakarta Mrs. Dr. } \\
\text { Dessy Sunarsi, SH MM } \\
\text { Drs. Nandar }\end{array}$ \\
\hline 3. & $\begin{array}{l}\text { Tuesday } \\
\text { Decem ber } \\
132016\end{array}$ & $\begin{array}{l}10: 00-12: 3 \\
\text { wib }\end{array}$ & $\begin{array}{l}\text { Counseling and } \\
\text { socalization of Child } \\
\text { Friendly Schools to } \\
\text { Students of SDN } 41 \text { Kaur. }\end{array}$ & $\begin{array}{l}\text { SDN } 41 \\
\text { Kaur }\end{array}$ & $\begin{array}{l}\text { Elly Dasna Taher } \\
\text { Dr. Dessy Sunarsi, } \\
\text { S.H.,MM }\end{array}$ \\
\hline 4. & $\begin{array}{l}\text { Selasa } 13 \\
\text { Desem ber } \\
2016\end{array}$ & $\begin{array}{l}\text { 13:00-14:00 } \\
\text { wib }\end{array}$ & $\begin{array}{l}\text { Symbolic giving of } \\
\text { textbook to SMPN } 35 \\
\text { Boarding School. }\end{array}$ & SMPN 35 & $\begin{array}{l}\text { Elly Dasna Taher } \\
\text { Dr. Dessy Sunarsi } \\
\text { S.H.,MM } \\
\text { \& Team }\end{array}$ \\
\hline
\end{tabular}


This activity lasts for 4 days from Tuesday 13 December to Friday 16 December 2016 with the following realization:

Table 3. Realization of First Day Activities December 13, 2016

\begin{tabular}{|l|l|l|l|l|}
\hline No & Time & Description of activities & place & information \\
\hline 01 & $09.00-10.00$ & $\begin{array}{l}\text { Opening Ceremony BIMTEK } \\
\text { Activities Establishment of Child } \\
\text { Friendly Schools in Kaur District }\end{array}$ & $\begin{array}{l}\text { Auditorium } \\
\text { BAPEDA District } \\
\text { Kaur }\end{array}$ & $\begin{array}{l}\text { Activities officially opened } \\
\text { by the District Secretary.Kaur }\end{array}$ \\
\hline 02 & $10.00-10.10$ & $\begin{array}{l}\text { Giving of books and educational } \\
\text { toys from the Ministry of State } \\
\text { PPPA to SDN 41 }\end{array}$ & $\begin{array}{l}\text { Aula SDN 41 } \\
\text { SDN 41 Kaur }\end{array}$ & Head of Basic Education \\
\hline 03 & $10.10-10.20$ & $\begin{array}{l}\text { Motivation with the screening of } \\
\text { the educational film Hellen Keller } \\
\text { Hall SDN 41 Kaur }\end{array}$ & $\begin{array}{l}\text { SDN 41 SDN 41 } \\
\text { Hall Kaur }\end{array}$ & $\begin{array}{l}\text { Dr. DessySunarsi, SH., } \\
\text { MM. dan Merry } \\
\text { Safarwati,S.Sos }\end{array}$ \\
\hline 04 & $10.20-11.30$ & $\begin{array}{l}\text { Child Psychology } \\
\text { SusmawarniTaher, SPsi, }\end{array}$ & $\begin{array}{l}\text { Aula SDN 41 } \\
\text { SDN 41 Kaur } \\
\text { Daesy } \\
\text { Ekayanthi,S.Pd.M.kom }\end{array}$ \\
\hline 05 & $11.30-12.30$ & Child Friendly School Program & $\begin{array}{l}\text { Aula SDN 41 } \\
\text { SDN 41 Kaur }\end{array}$ & $\begin{array}{l}\text { Eka Trina Setowati } \\
\text { Ira Mulyati S.T.Ms }\end{array}$ \\
\hline 06 & $12.30-12.40$ & Closing & $\begin{array}{l}\text { SDN 41 SDN 41 } \\
\text { Kaur }\end{array}$ & \begin{tabular}{l} 
Dr. DessySunarsi,SH.MM \\
\hline
\end{tabular} \\
\hline
\end{tabular}

Table 4. Realization of Second Day ActivitiesWednesday, December 142016

\begin{tabular}{|c|c|c|c|c|}
\hline No & Time & Description of activities & Place & Information \\
\hline 01 & $08.00-08.20$ & $\begin{array}{l}\text { Opening Ceremony of Counseling } \\
\text { Activities and Socialization of the } \\
\text { Formation of Child Friendly Schools } \\
\text { in SMPN } 36 \\
\text { - Opening by MC } \\
\text { - Sing IndonesianRaya songs } \\
\text { - Message from the Head of SMPN } \\
\text { 36 PKLK } \\
\text { - Message from the Curriculum } \\
\text { Head Education Agency and } \\
\text { Kab. Culture Kaur }\end{array}$ & \begin{tabular}{|lll} 
SMPN & 36 & Hall \\
PKLK & & \\
& & \\
& & \\
& & \\
& &
\end{tabular} & $\begin{array}{l}\text { The socialization was } \\
\text { officially opened by } \\
\text { the Head of the } \\
\text { Curriculum Division of } \\
\text { the Education and } \\
\text { Culture Office of the } \\
\text { Regency. Kaur }\end{array}$ \\
\hline 02 & $08.20-08.40$ & $\begin{array}{l}\text { Motivation with the delivery of the } \\
\text { Hellen Keller Short Film screening }\end{array}$ & $\begin{array}{lll}\text { SMPN } & 36 & \text { Hall } \\
\text { PKLK } & & \end{array}$ & $\begin{array}{l}\text { Dr. DessySunarsi, } \\
\text { SH., MM. } \\
\text { Ekaterina Setyawati, } \\
\text { ST.MT }\end{array}$ \\
\hline 03 & $08.40-10.30$ & PsichologyAnak & $\begin{array}{lll}\text { SMPN } & 36 & \text { Hall } \\
\text { PKLK } & & \end{array}$ & $\begin{array}{l}\text { Susmawarni Taher, } \\
\text { SPsi, M.Psi and } \\
\text { Daesy } \\
\text { Ekayanthi,S.Pd }\end{array}$ \\
\hline 04 & $10.30-11.50$ & Child Friendly School Program & $\begin{array}{l}\text { Aula SMPN } 36 \\
\text { PKLK }\end{array}$ & $\begin{array}{l}\text { Merry } \\
\text { Safarwati,S.Sos }\end{array}$ \\
\hline 05 & $11.50-12.00$ & closing & $\begin{array}{lll}\text { Aula } & \text { SMPN } 36 \\
\text { PKLK } & & \\
\end{array}$ & $\begin{array}{l}\text { Dr. DessySunarsi, } \\
\text { SH., MM. }\end{array}$ \\
\hline
\end{tabular}


Table 5. Realization of Third Day ActivitiesThursday, December 152016

\begin{tabular}{|l|l|l|l|l|}
\hline No & Time & Description of activities & Place & Information \\
\hline 01 & $08.15-08.30$ & $\begin{array}{l}\text { The opening of the Communication } \\
\text { material with the visualization of } \\
\text { the "Scorched Bread Case" in order } \\
\text { to build empathy }\end{array}$ & $\begin{array}{l}\text { SMPN 36 hall } \\
\text { PKLK }\end{array}$ & $\begin{array}{l}\text { Dr. DessySunarsi, } \\
\text { SH., MM. }\end{array}$ \\
\hline 02 & $08.30-10.15$ & -- Parenting & $\begin{array}{l}\text { SMPN 36 } \\
\text { hallPKLK }\end{array}$ & $\begin{array}{l}\text { SusmawarniTaher, } \\
\text { S.Psi, M.Psi } \\
\text { Merry Safarwati, } \\
\text { S.Sos.M.Si }\end{array}$ \\
\hline 03 & $10.15-11.50$ & Child Friendly School Program & $\begin{array}{l}\text { SMPN 36 hall } \\
\text { PKLK }\end{array}$ & $\begin{array}{l}\text { Daesy Ekayanthi, } \\
\text { S.Pd.MIK } \\
\text { Ira Mulyati S.T.Ms }\end{array}$ \\
\hline 04 & $11.50-12.00$ & Closing & $\begin{array}{l}\text { SMPN 36 } \\
\text { hallPKLK }\end{array}$ & $\begin{array}{l}\text { Dr. DessySunarsi, } \\
\text { SH.MM }\end{array}$ \\
\hline 05 & $12.00-13.00$ & $\begin{array}{l}\text { Review of the location of } \\
\text { dormitories and discussions with } \\
\text { mothers and caregivers }\end{array}$ & $\begin{array}{l}\text { SMPN 36 } \\
\text { hostelPKLK }\end{array}$ & \begin{tabular}{l} 
Implementation Team \\
\hline
\end{tabular} \\
\hline
\end{tabular}

Table 6. Realization of FourthDayActivitiesFriday, December16 2016

\begin{tabular}{|l|l|l|l|l|}
\hline No & Time & Description of activities & Place & Information \\
\hline 01 & $08.00-08.15$ & $\begin{array}{l}\text { Opening by Head of SDN 41 Kaur } \\
\text { Mr. Alimin, S.Pd. }\end{array}$ & SDN 41 hall & BapakAlimin, S.Pd. \\
\hline 02 & $08.15-08,30$ & $\begin{array}{l}\text { The opening of the Communication } \\
\text { material with the visualization of the } \\
\text { "Scorched Bread Case" in order to } \\
\text { build empathy }\end{array}$ & SDN 41 hall & $\begin{array}{l}\text { Dr. DessySunarsi, SH., } \\
\text { MM. } \\
\text { Daesy Ekayanthi, S,Pd. } \\
\text { MIK }\end{array}$ \\
\hline 03 & $08.30-10.00$ & $\begin{array}{l}\text { - Parenting } \\
- \text { Question and answer discussion }\end{array}$ & SDN 41 hall & $\begin{array}{l}\text { SusmawarniTaher,S.Psi } \\
\text { M.Ps } \\
\text { Merry Safarwati, S.Sos }\end{array}$ \\
\hline 04 & $10.00-11.10$ & Child Friendly School Program & SDN 41 hall & $\begin{array}{l}\text { IkaTerina } \\
\text { Ira Mulyati S.T.Ms }\end{array}$ \\
\hline 05 & $11.10-11.15$ & Closing & $\begin{array}{l}\text { SMPN 36 hall } \\
\text { PKLK }\end{array}$ & BapakAlimin, S.Pd. \\
\hline
\end{tabular}

\section{Activity Implementation Coverage}

Community service activities by the Gender Usahid Study Center on the mainstreaming of children's rights in Kaur district through the establishment of Child Friendly Schools are activities that take a lot of attention from both the community and the media. This can be seen from the many media that are enthusiastic to cover the entire series of activities. This activity has been covered through print media, electronic media and online media. Some electronic media coverage are RRI Bintuhan, TVRI Kaur, TVRI Kaur. In the form of print media, activities are covered by Kaur radar and the people of Bengkulu and Lampung Post. The coverage of online media activities is carried out through: Lampung Post.com, indonesianstudy.com, website. In addition, the spirit of this activity was also seen through RRI bintuhan who invited specifically Dr. Dessy Sunarsi, SH, MM in an interactive dialogue session on Wednesday edition, 14 December 201609.00 - 10.00 West Indonesia Time, which aired in parallel with National RRI. It is hoped that this interactive dialogue will motivate the people of Kaur Regency to increase their awareness about the protection of children's rights and the formation of child-friendly schools. 


\section{CONCLUSION}

\section{Conclusion}

Based on the results of the implementation of the activity, the following can be concluded:

a. The Kaur Regency Government and School leaders in Kaur District do not understand what is Child Friendly Schools initiated by the Ministry of Women's Empowerment and Child Protection of the Republic of Indonesia.

b. Establishment of pilot projects Child Friendly Schools in SDN 41 Kaur and SMPN 36 Special Education Special Services are very appropriate to encourage the emergence of awareness of Child Friendly Schools.

c. This pilot project school is in dire need of assistance for a conducive method in supporting the Child Friendly School Program in its future and sustainable application.

\section{Recomandation}

a. Guidelines on Child Friendly School Programs to be made clear and detailed, so that they are easily understood by the public.

b. In order to be given upgrading to teachers of SDN 41 and SMPN 36 PKLK about enrichment and the ability of teachers in teaching methods that are representative of children.

c. The Kaur District Government needs to receive intensive and integrative counseling on Gender awareness and Mainstreaming of Children's Rights directly guarded by the Ministry of Women's Empowerment and Child Protection

\section{REFERENCES}

Frondizi, R. (2001). Introduction to Value Philosophy. Yogyakarta: Student Library.

Indonesian Union's women's and gender study center,(2007), women's human rights legal instruments to realize gender justice, revised edition, Jakarta: Indonesian Torch Foundation

Minister of Women's Empowerment and Child Protection Regulation No. 8 of 2014 concerning the policy of child-friendly schools

Yulfita, Raharjo D.J.( 2012)Gender Concept - Gender Mainstreaming And Gender Responsive Budget, , Lipi

Act No. 23 of 2002 concerning child protection

Act No. 20 of 2003 concerning National Education

http://bp3akb.jabarprov.go.id/mengenal-dan-mengembangkan-sekolah-ramah-anak/ (diunduh tagl 2 September 2016)

http://visiuniversal.blogspot.co.id/2015/mengenal-dan-mengembangkan-sekolah.html (diunduh tanggal 3 September 2016) 